\title{
Origin, variability and age of biomass burning plumes intercepted during BORTAS-B
}

\author{
D. P. Finch ${ }^{1}$, P. I. Palmer ${ }^{1}$, and M. Parrington ${ }^{1, *}$ \\ ${ }^{1}$ School of GeoSciences, University of Edinburgh, Edinburgh, UK \\ * now at: the European Centre for Medium-range Weather Forecasts, Reading, UK
}

Correspondence to: D. P. Finch (d.finch@ed.ac.uk)

Received: 14 February 2014 - Published in Atmos. Chem. Phys. Discuss.: 31 March 2014

Revised: 20 November 2014 - Accepted: 23 November 2014 - Published: 23 December 2014

\begin{abstract}
We use the GEOS-Chem atmospheric chemistry transport model to interpret aircraft measurements of carbon monoxide (CO) in biomass burning outflow taken during the 2011 BORTAS-B campaign over eastern Canada. The model has some skill reproducing the observed variability, with a Spearman's rank correlation $r_{\mathrm{s}}=0.65$, but has a positive negative bias for observations $<100 \mathrm{ppb}$ and a negative bias for observations $>300 \mathrm{ppb}$. We find that observed $\mathrm{CO}$ variations are largely due to fires over Ontario, as expected, with smaller and less variable contributions from fossil fuel combustion from eastern Asia and NE North America. To help interpret observed variations of $\mathrm{CO}$ we develop a Eulerian effective physical age of emissions $(\bar{A})$ metric, accounting for mixing and chemical decay, which we apply to pyrogenic emissions of $\mathrm{CO}$. We find that during BORTAS-B the age of emissions intercepted over Halifax, Nova Scotia is typically $4-11$ days, and on occasion as young as two days. We show that $\bar{A}$ is typically $1-5$ days older than the associated photochemical ages inferred from co-located measurements of different hydrocarbons. We find that the frequency distribution of differences between the age measures $(\Delta \tau)$ in plumes (defined by $\mathrm{CH}_{3} \mathrm{CN}>150 \mathrm{ppt}$ ) peaks at 3 days. This corresponds to a chemical retardation of $50 \%$. We find a strong relationship in biomass burning plumes between $\bar{A}$ and $\Delta \tau\left(r^{2}=0.80\right)$, which is not present outwith these plumes $\left(r^{2}=0.28\right)$. We argue that these observed relationships, together with a robust observed relationship between $\mathrm{CO}$ and black carbon aerosol during BORTAS-B $\left(r^{2}>0.7\right)$, form the basis of indirect evidence that aerosols co-emitted with gases during pyrolysis markedly slowed down the plume photochemistry during BORTAS-B with respect to photochemistry at the same latitude and altitude in clear skies.
\end{abstract}

\section{Introduction}

The open burning of biomass is an inefficient combustion process, resulting in the release of a wide range of chemically reactive gases and particles that contribute to the production of ozone in the troposphere (Goode et al., 2000; Koppmann et al., 2005; Akagi et al., 2011), with implications for national surface air quality and air quality mitigation strategies. However, the rate and extent of photochemical ozone production in biomass burning outflow is still a matter of debate that largely reflects the sensitivity of results to environmental conditions (Jaffe and Wigder, 2012). In this paper we present an analysis of measurements of carbon monoxide (CO) from the BORTAS-B aircraft campaign during July 2011 (Palmer et al., 2013), in conjunction with a 3-D chemistry transport model to understand the processes that determine observed $\mathrm{CO}$ variability and relate the ages of emissions to the observed photochemical production of ozone.

Ozone production within biomass burning plumes intercepted during the BORTAS-B campaign (Palmer et al., 2013) has previously been studied using photochemical age (Parrington et al., 2013; Parrish et al., 2007). Estimating the photochemical age of a pyrogenic air mass relies on an accurate knowledge of the hydroxyl $(\mathrm{OH})$ radical, and assumes constant trace gas emission factors from pyrogenic processes. However, despite these weaknesses the photochemical age is still a useful metric for helping to interpret observed trace gas variations. We introduce a complementary (weighted-mean) effective physical age metric $\bar{A}$. Using $\bar{A}$ we can infer age distributions within an air mass and by comparing $\bar{A}$ with the photochemical age we can estimate how the physical and chemical environment of the plume has modified the speed of the in situ plume chemistry. 
The main source of $\mathrm{CO}$ is the incomplete combustion of fossil fuel, biomass, and biofuel. There is also a source of $\mathrm{CO}$ from oxidation from methane and non-methane volatile organic compounds (NMVOCs) (Duncan et al., 2007). The main sink is from the oxidation by $\mathrm{OH}$, resulting in an atmospheric lifetime of weeks to months depending on latitude and season. We use airborne $\mathrm{CO}$ measurements from phase B of the Quantifying the Impacts of BOReal forest fires on Tropospheric oxidants over the Atlantic using Aircraft and Satellites (BORTAS-B) project, July 2011. The overall objective of BORTAS was to better understand the production of tropospheric ozone with respect to the chemical evolution of plumes from boreal forest fires, which was achieved by integrating aircraft (Lewis et al., 2013; Le Breton et al., 2013; O'Shea et al., 2013), surface (Gibson et al., 2013; Griffin et al., 2013), sonde (Parrington et al., 2012), and satellite measurements (Tereszchuk et al., 2013) of atmospheric composition. Phase A of BORTAS was conducted without aircraft in July 2010 (Parrington et al., 2012).

In the next section we briefly describe the $\mathrm{CO}$ data we analyse. The GEOS-Chem chemistry transport model is described in Sect. 3, including a description of a new age of emission calculation which we use to interpret the data. Our results are reported in Sect. 4, including a statistical analysis of the data and a model interpretation of the data. We give our conclusions in Sect. 5.

\section{Data and methods}

\subsection{BORTAS-B carbon monoxide and $\mathrm{CH}_{3} \mathrm{CN}$ data}

Here we use data exclusively from the BORTAS-B aircraft campaign. The focus of the work shown here is the analysis of $\mathrm{CO}$ measurements, which were operated by the Facility for Airborne Atmospheric Measurements on the BAe-146 atmospheric research aircraft using a fast-response vacuumUV resonance fluorescence instrument (Gerbig et al., 1999). The instrument has an averaging time of $1 \mathrm{~s}$ and a precision and accuracy of $1 \mathrm{ppb}$ and $3 \%$, respectively. We use measurements of acetonitrile $\left(\mathrm{CH}_{3} \mathrm{CN}\right.$, not shown), an additional tracer of biomass burning, measured by proton transfer reaction mass spectrometer (Murphy et al., 2010), to isolate plumes within BORTAS-B. These measurements have a mean precision of $37 \mathrm{ppt}$ during BORTAS-B (Palmer et al., 2013). We define plumes as $C O$ measurements corresponding to $\mathrm{CH}_{3} \mathrm{CN}>150 \mathrm{ppt}$.

\subsection{The GEOS-Chem atmospheric chemistry model}

We use the GEOS-Chem atmospheric chemistry model (www.geos-chem.org) to interpret the BORTAS-B CO measurement. The model has been documented extensively (e.g. Bey et al., 2001; Duncan et al., 2007; Gonzi et al., 2011; Parrington et al., 2012) and here we include only the details relevant to our study.
We use v9-01-03 of the model, driven by GEOS-5 assimilated meteorological data from the NASA Global Modelling and Assimilation Office (GMAO) Goddard Earth Observing System (GEOS). For global simulations we use a spatial resolution of $2^{\circ}$ latitude by $2.5^{\circ}$ longitude (a degradation of the native resolution of $0.5^{\circ} \times 0.667^{\circ}$ ) with 47 vertical levels with a temporal resolution of $30 \mathrm{~min}$. For the model runs used to compare against BORTAS-B aircraft data and the $\bar{A}$ calculations, we use the native model resolution with 47 vertical levels. We use the Global Fire Emissions Database (GFED-3), describing biomass burning emissions (Giglio et al., 2010), which has a three hour temporal resolution; fossil fuel emissions from the Emissions Database for Global Atmospheric Research (EDGAR, Olivier et al., 1999); and biogenic emissions from the Model of Emissions of Gases and Aerosol from Nature (MEGAN, Guenther et al., 2006). We report model calculations from the summers (June, July, August - JJA) of 2008-2011. We initialize the model in 2007, using previous model output, and run using a single total CO tracer for 9 months until our study period, JJA 2008. During the summer periods we use "tagged" tracers (described below) and between the successive summer periods we collapse these tagged tracers back to the single tracer for computational expediency.

For the $\mathrm{CO}$ attribution calculations, we use a "tagged" version of the model (e.g. Jones et al., 2003; Palmer et al., 2003, 2006; Feng et al., 2009; Fisher et al., 2010), which uses pre-calculated monthly 3-D OH fields that correspond to a methyl chloroform lifetime of 6.3 years. Using these fields allows us to linearly decompose the $\mathrm{CO}$ originating from specific processes and geographical regions. Figure 1 shows the geographical regions we use. For biomass burning in the Northern Hemisphere we split North America into four quadrants, consider Europe as one region, and split Russia/Siberia into three regions (western, mid, and eastern). We show below that most of the observed $\mathrm{CO}$ over eastern Canada during JJA originates from these regions. For Northern Hemisphere fossil fuel sources we have combined some regions that do not play a significant role in the interpretation of the BORTAS-B data. The chemical source of $\mathrm{CO}$ from the oxidation of methane and NMVOCs is treated as one global tracer. In total, we have 28 tracers (including the background) that sum to the total atmospheric CO. Wherever we compare the model against data we sample the model at the time and location of the measurement.

\subsection{Age of emission model calculation}

We use the same model structure for the "tagged" CO simulation to calculate $\bar{A}$. To calculate $\bar{A}$, we adapt the model to instead emit an arbitrary constant amount to a day-specific tracer wherever there is active burning during our study period (informed by GFED-3). Once emitted, the tracer is left to disperse. We assume an atmospheric lifetime $\tau$ of 60 days for the emitted tracers, and therefore a constant reaction rate 


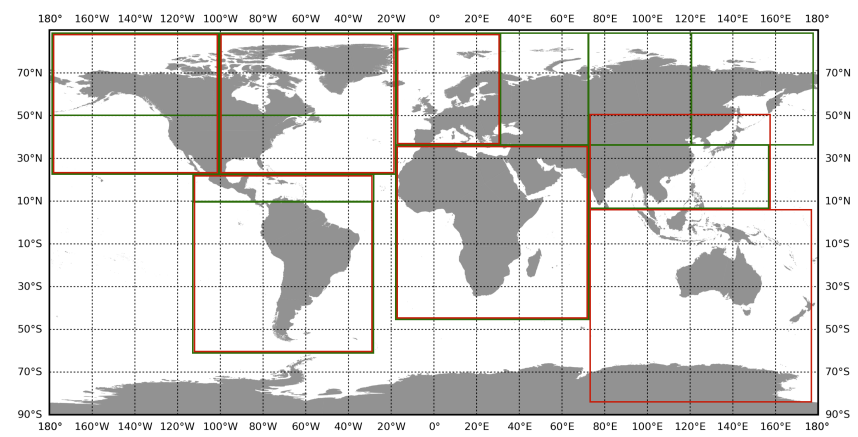

Figure 1. Source regions for the tagged CO simulation. Regions outlined in red denote fossil fuel tagged tracers; regions outlined in green refer to biomass burning tagged tracers.

$k$. If we assume that this lifetime is determined by oxidation by $\mathrm{OH}$, as it is for $\mathrm{CO}$, it corresponds to an $\mathrm{OH}$ concentration of $1.9 \times 10^{6}$ molec $\mathrm{cm}^{-3}$. The age $(A)$ of each tracer is determined by the number of days since the start of the run minus the tracer number (not value). For example, after a 31-day model run, tracer number 1 has an age of 30 days and tracer number 20 has an age of 11 days. At the end of a 31 day simulation for July, say, we have 31 tracers, each containing the biomass burning emissions from the corresponding day.

To account for older air being subject to more dispersion than younger air, we define an effective age of air $\bar{A}$ at vector position $\boldsymbol{x}$ and time $t$ :

$\bar{A}(\boldsymbol{x}, t)=\frac{\sum_{i=1}^{n} A_{i}(\boldsymbol{x}, t) L_{\mathrm{M}, i}(\boldsymbol{x}, t) L_{\mathrm{C}, i}(t)}{\sum_{i=1}^{n} L_{\mathrm{M}, i}(\boldsymbol{x}, t) L_{\mathrm{C}, i}(t)}$,

which represents a weighted mean of the age of each tracer $A_{i}(\boldsymbol{x}, t)$, where $i$ denotes the model day when a tracer was released at the surface. For example, the effective age of emissions on day ten is the weighted mean of the tracers released from days 1 to 10 . Individual age tracers take account of atmospheric mixing $L_{\mathrm{M}, i}(\boldsymbol{x}, t)$, which is determined by the value of the tracer after it has been dispersed in the model, and the chemical loss of tracer $L_{\mathrm{C}, i}(t)=\exp ^{-t / \tau}$. More generally, we can extend this formulation to include other sink terms such as dry and wet deposition. This method does not account for the magnitude of $\mathrm{CO}$ emitted from any fire, regardless of its size.

For this paper, calculating $\bar{A}$ allows us to quantify the physical age of emissions intercepted during BORTAS-B, providing additional information to interpret the chemical signature of the sampled air masses. It also allows us to determine whether the air masses intercepted during BORTASB were representative of that summer and of a similar period from preceding years. This method does not account for model transport error.

We compare our $\bar{A}$ estimates against the associated photochemical ages of plumes intercepted in BORTAS-B (Par- rington et al., 2013). The photochemical age is the time taken for a tracer to be photochemically removed from a biomass burning plume. It is based on ratios of NMVOCs close to the emission source (here, determined by flight B626 in the BORTAS-B campaign over Northwestern Ontario on 26 July 2011) and the ratio of NMVOCs at the time of observations.

The photochemical age of an air parcel is directly proportional to the constant, mean $\mathrm{OH}$ concentration integrated along its path $<[\mathrm{OH}]>$ from the point of emission at time $t_{\mathrm{E}}$ to the time of observation $t_{\mathrm{O}}$ (Parrish et al., 2007):

$$
\begin{aligned}
& t_{\mathrm{a}}=\frac{1}{<[\mathrm{OH}]>} \int_{i=t_{\mathrm{E}}}^{t_{\mathrm{O}}}[\mathrm{OH}] \mathrm{d} t \\
& =-\frac{1}{<k_{A}><[\mathrm{OH}]>} \ln \left(\frac{[A]_{\mathrm{E}}}{[A]_{\mathrm{O}}}\right),
\end{aligned}
$$

where $t_{\mathrm{a}}$ denotes the photochemical lifetime of the air parcel due to $\mathrm{OH}$, and $<k_{A}>$ represents an average reaction rate constant for $A$ with $\mathrm{OH}$ (in this case, taken from Atkinson and Arey, 2003) with a constant temperature of $273 \mathrm{~K}$. $[A]_{\mathrm{E}}$ and $[A]_{\mathrm{O}}$ are the concentrations of an NMVOC at the the time of emission and observation, respectively, used to determine $t_{\mathrm{a}}$

Extending this approach by using the ratio of two NMVOCs with different atmospheric lifetimes against oxidation by $\mathrm{OH}$ allows us to calculate the photochemical age without having to know the concentration of either gas at the point of emission:

$$
\begin{aligned}
& t_{\mathrm{a}}=\frac{1}{<[\mathrm{OH}]>} \int_{i=t_{\mathrm{E}}}^{t_{o}}[\mathrm{OH}] \mathrm{d} t \\
& =-\frac{1}{<[\mathrm{OH}]><k_{A}-k_{B}>}\left\{\ln \frac{[A]_{\mathrm{E}}}{[A]_{\mathrm{O}}}-\ln \frac{[B]_{\mathrm{E}}}{[B]_{\mathrm{O}}}\right\},
\end{aligned}
$$

where $\left[A_{\mathrm{E}}\right] /\left[B_{\mathrm{E}}\right]$ represents an emission factor that can be taken from independent measurements. Both equations rely on an accurate knowledge of $\mathrm{OH}$ to anchor the calculation: halving the assumed $\mathrm{OH}$ concentration doubles the photochemical lifetime and vice versa.

Both methods used to estimate age assume a mean value for $\mathrm{OH}$ (via a prescribed lifetime for $\bar{A}$ ) and a reaction rate constant that does not account for changes in temperature and pressure along the path of the air parcel. These common assumptions allow us to directly compare the results from the two methods and to determine the extent of the photochemical retardation.

Photochemical age and $\bar{A}$ are equivalent if the photochemical environment is determined solely by $\mathrm{OH}$ and we have perfect knowledge of this loss term. For plumes with a photochemical age that is younger than $\bar{A}$ we can assume that the associated photochemistry has been retarded. For an arbitrary gas, retardation processes include gas-phase or heterogeneous chemistry, or incoming solar radiation extinction 

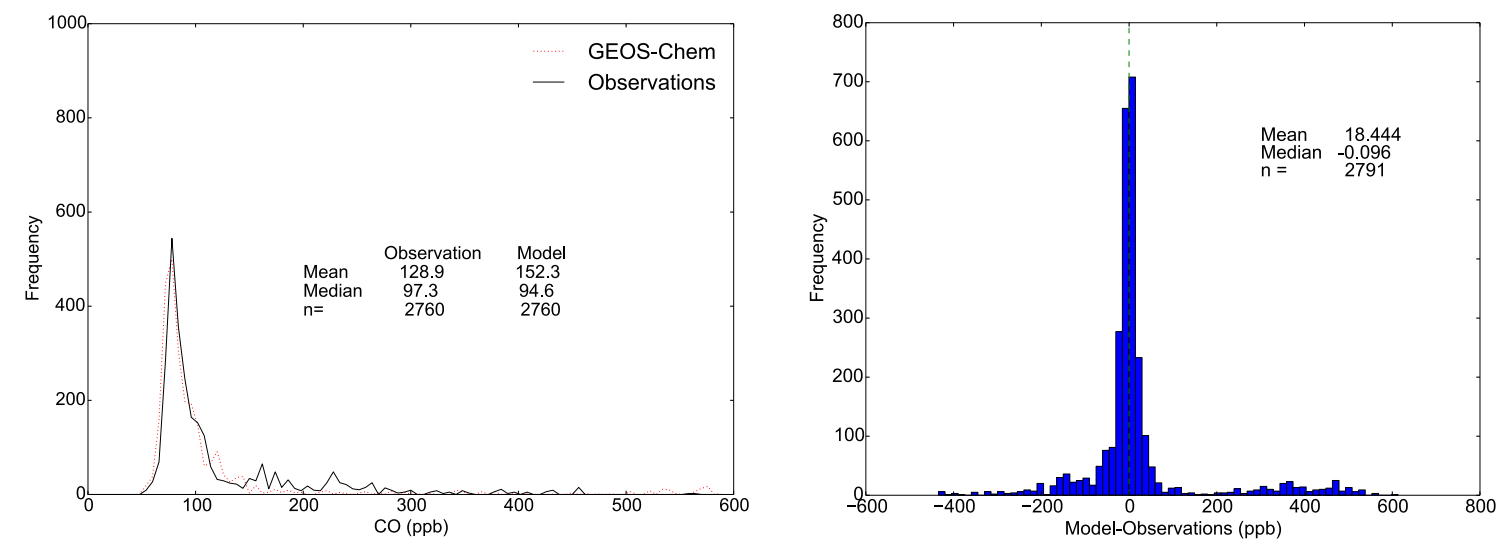

Figure 2. Statistical comparison of model and observed CO from BORTAS-B. The observations have been averaged over the $2^{\circ} \times 2.5^{\circ}$ model grid. Left-hand panel shows the frequency distributions; right-hand panel show the frequency distribution of the model minus observed CO residuals. Mean and median values are shown on each panel.

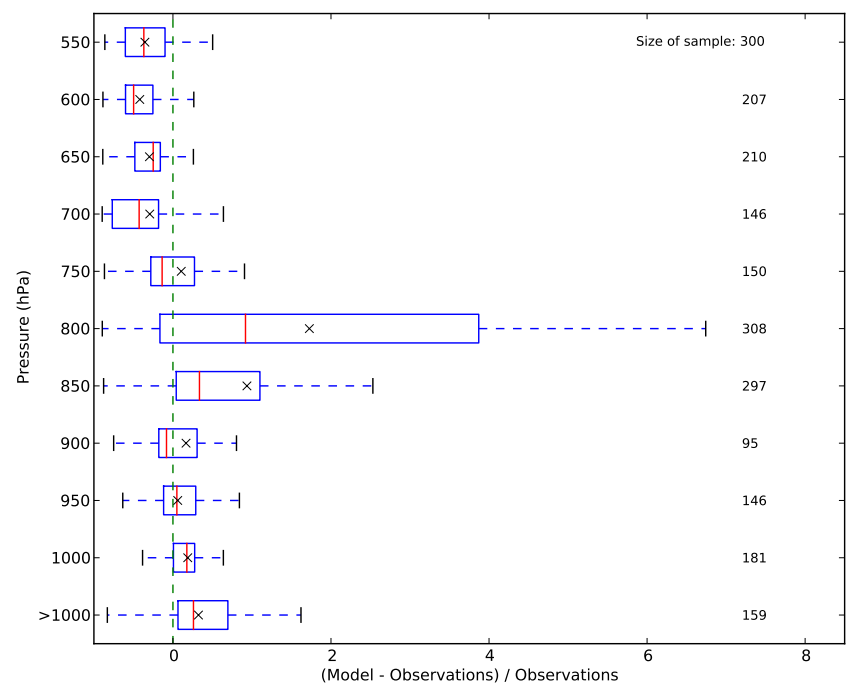

Figure 3. Relative model error in the GEOS-Chem simulation of CO during BORTAS-B as a function of altitude described by the box and whiskers approach. The red line and grey cross denote the median and mean values, respectively.

via aerosol or clouds; for $\mathrm{CO}$ emitted from pyrogenic processes it is most likely that associated aerosol optical depths are the culprit for decreased $\mathrm{OH}$. Plumes with a photochemical age that is older than $\bar{A}$ suggest a significant error in $\mathrm{OH}$ or with model transport.

\section{Results}

\subsection{Statistical analysis of BORTAS-B CO data}

Figure 2 shows the model and observed CO frequency distributions. Observed $\mathrm{CO}$ concentrations show a long tail of high concentrations with the highest of these values not re- produced by the model, which is reflected by the mean and median concentration values. The median model minus observed $\mathrm{CO}$ value is $-0.1 \mathrm{ppb}$. We find the model has a positive bias for observations $\leq 100 \mathrm{ppb}$ and a negative bias for observations $>300 \mathrm{ppb}$. The largest discrepancies between the model and the observations generally occur at the largest values of $\mathrm{CO}$. The 99th percentile value for model and observed CO concentrations are 670 and $436 \mathrm{ppb}$, respectively. The interquartile range for BORTAS-B CO concentration data is $87-133 \mathrm{ppb}$, which is consistent with data from the NASA ARCTAS-B campaign (Arctic Research of the Composition of the Troposphere from Aircraft and Satellites, Jacob et al., 2010). The largest observed CO concentrations during BORTAS-B are larger than those observed during ARCTAS-B (Liang et al., 2011). Figure 3 shows that the relative model error [model minus observation]/model is typically within \pm 0.5 but has a range of \pm 1.0 . The model overestimates observed $\mathrm{CO}$ concentrations between the surface and $800 \mathrm{hPa}$, reflecting the outflow of anthropogenic and biomass burning pollution, with the largest discrepancy around $800 \mathrm{hPa}$. The model generally has more skill in reproducing the variability of observed CO during BORTAS-B below $4 \mathrm{~km}$ (Spearman's rank correlation $r_{\mathrm{s}}=0.65$ ) than above $4 \mathrm{~km}\left(r_{\mathrm{s}}=0.19\right)$. In this case we use Spearman's rank correlation because it is a more appropriate metric that can describe the model's ability to reproduce qualitatively observed elevated values (plumes) above a background but cannot necessarily capture the value of these elevated values. The inability of the model to capture these elevated values may reflect errors in emissions and/or atmospheric transport.

\subsection{Tagged CO model output}

Table 1 shows the tagged model analysis sampled at the times and locations of the BORTAS-B CO measurements. The largest source of $\mathrm{CO}$ and the largest source of $\mathrm{CO}$ variability during BORTAS was biomass burning in Ontario, as 


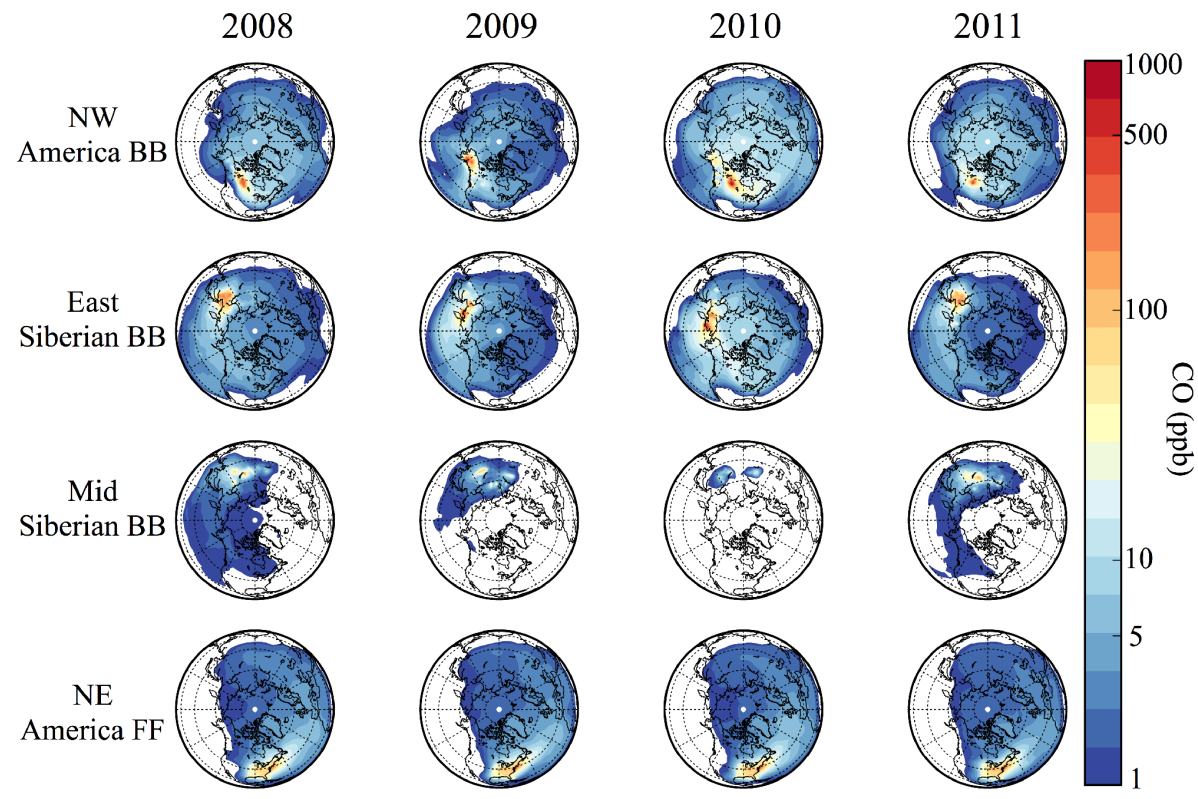

Figure 4. Mean June-August GEOS-Chem model surface CO concentrations (ppb) from the four largest sources over the Northern Hemisphere for 2008-2011. Individual contributions (Fig. 1) are from NW North America biomass burning emissions (first row), NE North America fossil fuel (second row), East Siberia biomass burning (third row), and mid-Siberia biomass burning (bottom row).

expected. There are also large but much less variable contributions from the background (air older than JJA) and from the oxidation of methane and NMVOCs. CO produced by $\mathrm{CH}_{4}$ oxidation typically contributes around $30 \%$ to global concentrations (Duncan et al., 2007).

Figure 4 shows the mean JJA model contributions of total surface $\mathrm{CO}$ from different geographically based sources 2008-2011, described using a horizontal resolution of $2^{\circ}$ latitude by $2.5^{\circ}$ longitude. The contribution from biomass burning over NW North America is broadly constant from year to year, although the distribution of the fires varies substantially, with Alaska playing a dominant role only in 2009 during our study period. The magnitude and the distribution of fossil fuel emissions from NE North America (predominantly the NE USA) appear reasonably consistent over the four years, with emissions generally travelling up the eastern seaboard with eventual outflow to the Atlantic Ocean close to Halifax, Nova Scotia. Similar to North America, Siberian biomass burning has substantial spatial variability from year to year, with its location playing a key role in determining its eventual impact on North America and Europe. During 2010 the largest CO concentrations originated from East Siberia and spread across the Northern Hemisphere. In contrast, during BORTAS-B in 2011 most of the fire activity was further SW and had less of an impact over eastern Canada. Fires from mid-Siberia had a larger influence on total $\mathrm{CO}$ during 2008-2009, with very little activity during 2010-2011. There is a consistently small contribution to BORTAS observations from fossil fuel combustion from East Asia (not shown), peaking at around $400 \mathrm{ppb}$ over China but quickly
Table 1. Contribution of $\mathrm{CO}$ from geographical sources averaged over all BORTAS-B flights, lumping all other contributions $<2 \mathrm{ppb}$ into "Other". "Background" refers to any residual CO before the beginning of the BORTAS-B period.

\begin{tabular}{lrr}
\hline Tracer source & $\begin{array}{r}\text { Mean } \\
(\mathrm{ppb})\end{array}$ & $\begin{array}{r}\text { SD } \\
(\mathrm{ppb})\end{array}$ \\
\hline NE USA and Canada biomass burning & 55.4 & 134.6 \\
East Asian fossil fuel & 11.9 & 3.4 \\
North East American fossil fuel & 7.9 & 15.4 \\
NW USA and Canada biomass burning & 6.2 & 4.5 \\
North West American fossil fuel & 3.4 & 2.2 \\
Mid-Siberia biomass burning & 2.0 & 0.7 \\
Other & 7.9 & 4.2 \\
Methane and NMVOCs & 45.5 & 12.4 \\
Background & 10.7 & 2.3 \\
\hline
\end{tabular}

dropping off to around $10 \mathrm{ppb}$ by the time it has crossed the Pacific. Differences between our Fig. 4 and Fig. 9 from Palmer et al. (2013), also showing polar CO concentrations during BORTAS-B, are due to different biomass burning inventories. Here, we use GFED-3 (see above) and Palmer et al. (2013) used the Fire Locating and Modeling of Burning Emissions inventory (Reid et al., 2009).

Figure 5 shows that biomass burning from NW North America is still a dominant factor in the variability of total CO in the free troposphere. During 2010, these fires contributed around $50 \mathrm{ppb}$ of $\mathrm{CO}$ into the upper troposphere, causing widespread pollution during July. Typically these 


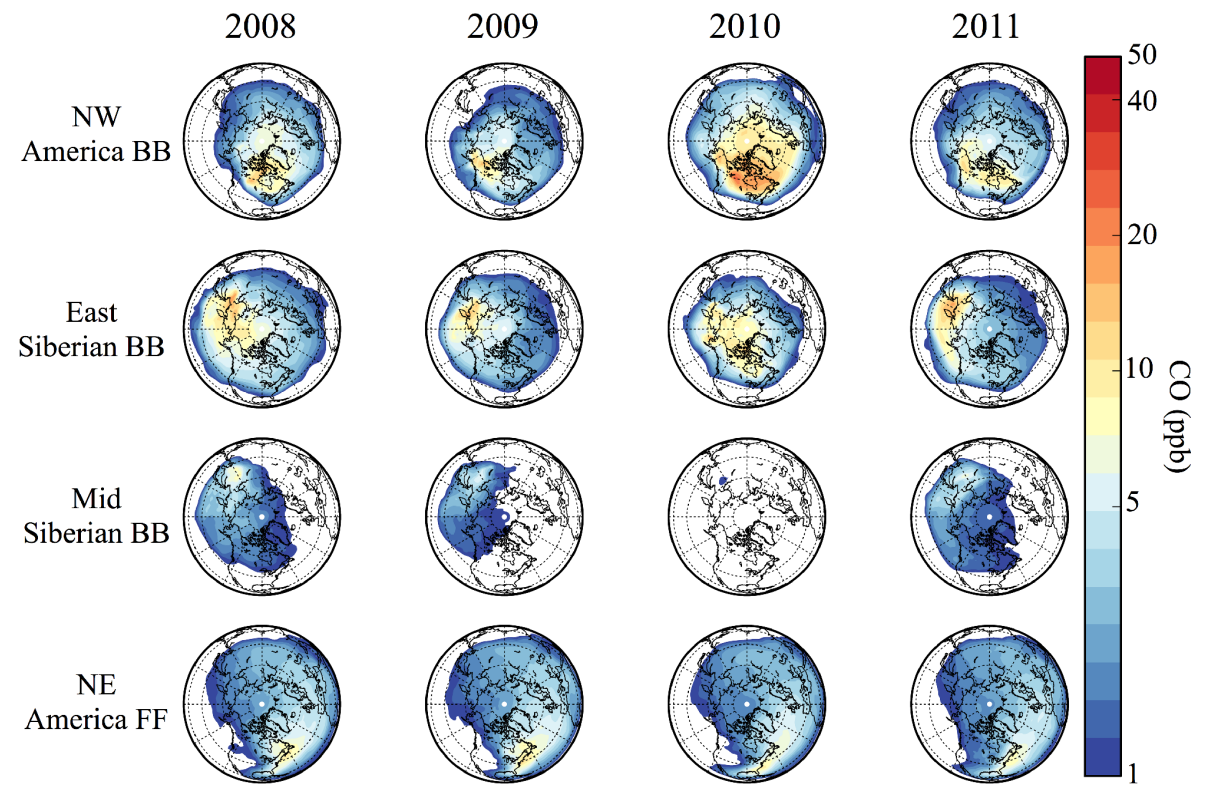

Figure 5. Same as Fig. 4 but at $4 \mathrm{~km}$ altitude. Note the different upper limit to the colour bar.

emissions contribute about $10 \mathrm{ppb}$ of $\mathrm{CO}$ over Europe. Contributions from east Siberia and mid-Siberia appear to be consistent over the 4 years except during 2010, when very little material is transported into the free troposphere. In general, the magnitude and distribution of the fossil fuel source is consistent across the 4 years, with weather systems lofting surface emissions to the free troposphere.

The widespread and persistent source of $\mathrm{CO}$ (approximately $10 \mathrm{ppb}$ ) from Asian anthropogenic sources over the Northern Hemisphere (not shown) agrees with the ARCTASA study (Fisher et al., 2010) and ARCTAS-B (Bian et al., 2013). Relative to ARCTAS-A, BORTAS-B generally shows a much larger contribution to the total $\mathrm{CO}$ from boreal biomass burning, reflecting the timing of ARCTAS-A in April 2008 before the beginning of the main fire season. For JJA 2008-2011 we find that boreal biomass burning represents a significant contribution to the total surface $\mathrm{CO}$ over the Western Arctic region defined as $50-90^{\circ} \mathrm{N}, 170-40^{\circ} \mathrm{W}$, following Bian et al. (2013). Analysis of ARCTAS-B data showed that boreal biomass burning contributed approximately $25 \%$ of CO in this region during July 2008 (Bian et al., 2013). We find that boreal biomass burning contributes $25-45 \%$ of the total CO for the defined Western Arctic region for all years, peaking at $>90 \%$ of the total $\mathrm{CO}$ over intense burning areas. During 2008 we find our results are broadly consistent with Bian et al. (2013) but at the lower end of their range. The discrepancy between these results is likely due to using different emission inventories, with Bian et al. (2013) using the Quick Fire Emissions Database.

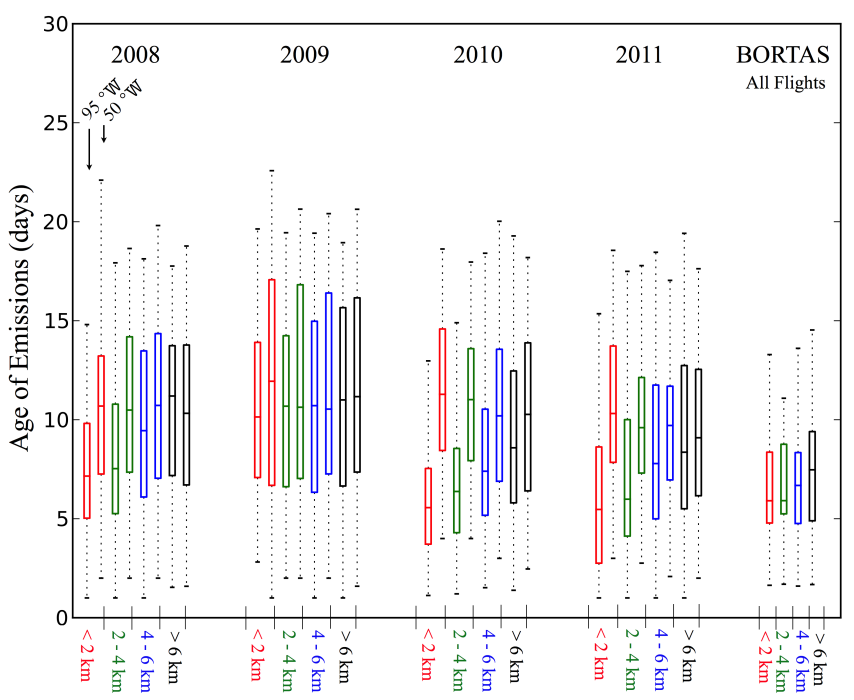

Figure 6. Box and whiskers plot showing the mean age of emissions for different altitudes ( $<2 \mathrm{~km}, 2-4 \mathrm{~km}, 4-6 \mathrm{~km}$, and $>6 \mathrm{~km})$ at the longitudinal boundaries of the BORTAS-B domain $\left(45^{\circ} \mathrm{N}-\right.$ $60^{\circ} \mathrm{N}, 95^{\circ} \mathrm{W}-50^{\circ} \mathrm{W}$ ) during July $2008,2009,2010,2011$, and for the model sampled along the BORTAS-B flights. Within the box, the upper, middle, and lower horizontal bars denote the first quartile, the median, and the third quartile. The full range of data is shown by the whiskers.

\subsection{Effective physical age of air}

Figure 6 shows the mean model statistics for $\bar{A}$ during July $2008-2011$ at 95 and $50^{\circ} \mathrm{W}$, averaged over $45-60^{\circ} \mathrm{N}$, representing the approximate western and eastern boundaries of the measurements sampled during BORTAS-B. We con- 


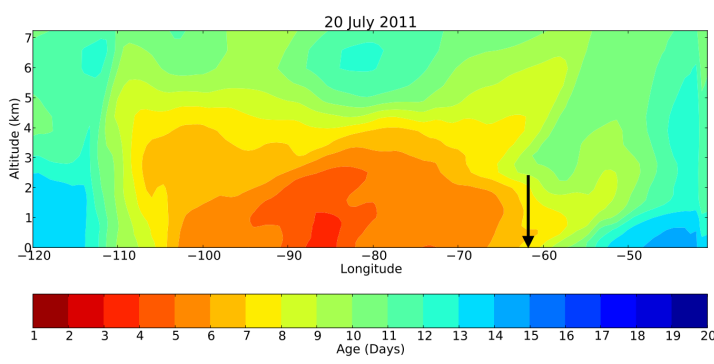

(a)

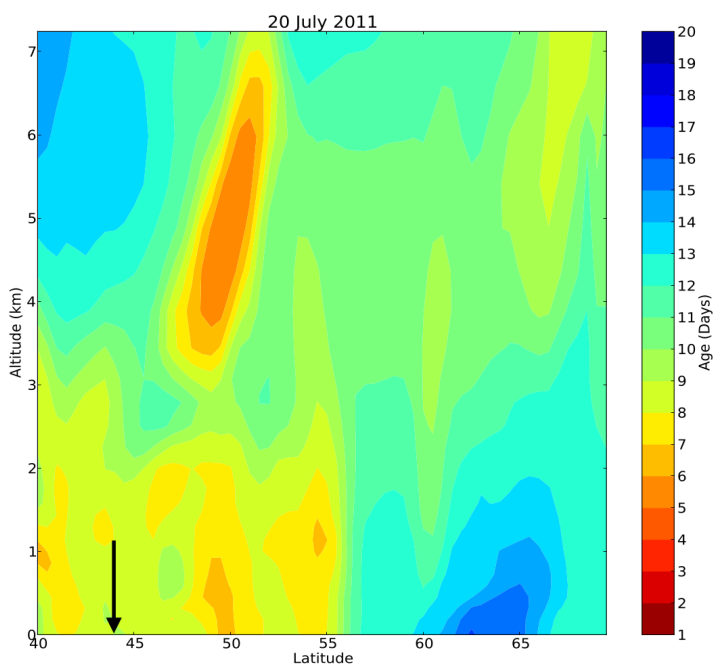

(b)

Figure 7. Age of emissions on 20 July 2011 (a) $120-40^{\circ} \mathrm{W}$ and $0-7 \mathrm{~km}$, averaged over $45-55^{\circ} \mathrm{N}$; and (b) $40-70^{\circ} \mathrm{N}$ and $0-7 \mathrm{~km}$ at $63^{\circ} \mathrm{W}$, the same longitude as the Dalhousie University, Halifax, NS, surface measurements (Palmer et al., 2013). Location of Dalhousie University is shown by the black arrow.

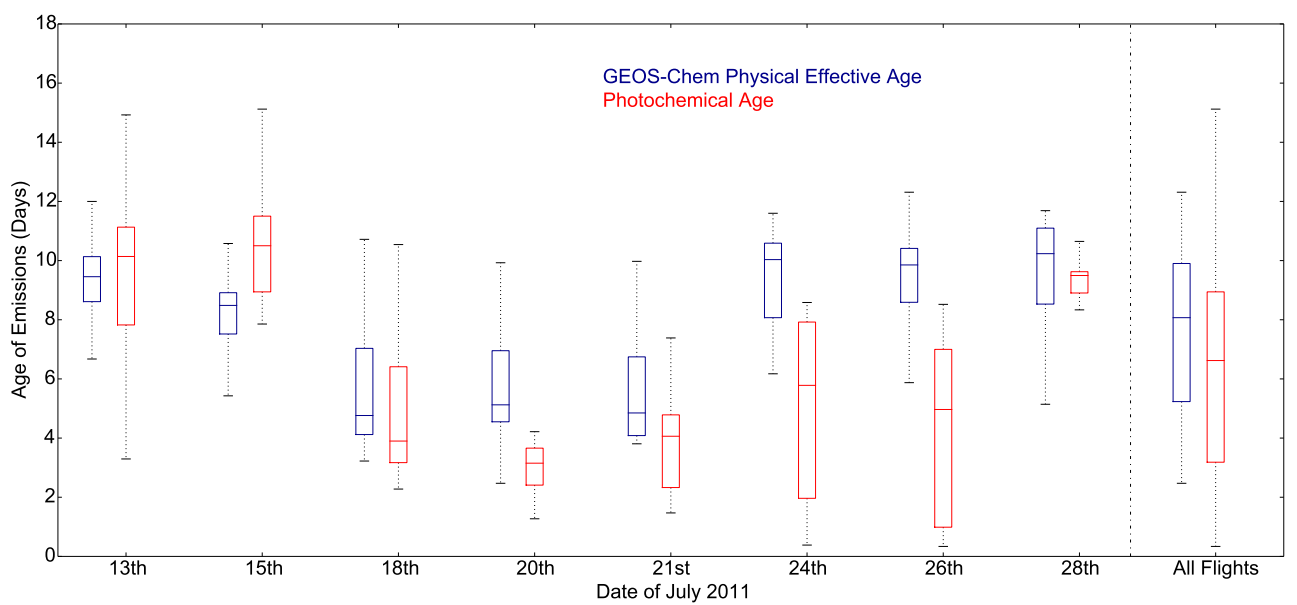

Figure 8. Box and whiskers plot of the age of air observed during individual BORTAS-B aircraft flights: photochemical age using BORTASB data (red) and effective age $\bar{A}$ using the GEOS-Chem model (blue). The box and whiskers plots for all flights are shown in the two right-hand columns. Within the box, the upper, middle, and lower horizontal bars denote the first quartile, the median, and the third quartile. The full range of data is shown by the whiskers.

sider four altitude bins, corresponding to the boundary layer $(0-2 \mathrm{~km})$, lower and mid troposphere $(2-4$ and $4-6 \mathrm{~km}$, respectively), and upper troposphere $(>6 \mathrm{~km})$. At the western boundary, emissions from 2008 have a median age of seven days, 2009 has a median age of 10 days, and 2010 and 2011 have a median age of five days. We find that the older age of emissions during 2009 is due to fewer fires along the western boundary and consequently a larger influence from Alaska and further afield. Air sampled at the eastern boundary is older, as expected with the exception of the upper troposphere $(>6 \mathrm{~km})$ which shows similar median ages from the western boundary to the eastern boundary. We find that the median age distributions for our study period at the eastern boundary were between 10 and 13 days, with a corresponding interquartile range of 7-13 days at altitudes $<2 \mathrm{~km}$ except for 2009, when there was an older interquartile age range of 7-17 days. The difference in $\bar{A}$ between the two boundaries decreases with increasing altitude; above $4 \mathrm{~km}$, ages are indistinguishable because air is more well-mixed and influenced by emissions outside the domain. Emissions clearly get older as they move from the west towards the Atlantic, with an increase in median age of approximately 
three days for all years except 2009, when the age difference between the west and east boundaries is approximately one day in the lower troposphere and insignificant at higher altitudes. We attribute this lack of ageing in 2009 to fewer Canadian fires during July, as mentioned above. Boreal biomass burning in 2009 started earlier in the year and was more prominent in Alaska and Siberia. Emissions tend to be older at $50^{\circ} \mathrm{W}$ at lower altitudes (not shown). This may be a result of fresher emissions being lofted higher into the atmosphere as they travel. Figure 6 also shows that the median value of $\bar{A}$ (six days) sampled during BORTAS-B falls within the range of model emission ages at $95^{\circ} \mathrm{W}$, with the majority of measurements taken $65-40^{\circ} \mathrm{W}$. We find a similar observed median value of $\bar{A}$ for all altitudes, which is typically lower than the model free troposphere. This bias towards younger ages reflects the sampling strategy of BORTAS-B, which was to intercept fresh biomass plumes.

Figure 7 shows an example of $\bar{A}$ on 20 July 2011, which is used as a case study in other BORTAS studies (e.g. Griffin et al., 2013; Franklin et al., 2014). Figure 7a shows longitudinal and latitudinal cross-section views of emissions as they are transported from the Thunder Bay region $\left(50^{\circ} \mathrm{N}, 88^{\circ} \mathrm{W}\right)$. By the time the plume is observed on 20 July by ground-based observatories over Toronto $\left(43.70^{\circ} \mathrm{N}, 69.40^{\circ} \mathrm{W}\right)$ (Griffin et al., 2013) and Halifax $\left(44.6^{\circ} \mathrm{N}, 63.59^{\circ} \mathrm{W}\right)$ (Franklin et al., 2014) the plume is approximately 5-7 days old, corresponding to an emission on 14-15 July. Figure $7 \mathrm{~b}$ shows that the transported air, intercepted at $63^{\circ} \mathrm{W}$, is composed of a young plume (4-5 days old) surrounded by older air (7 days old) over $47-55^{\circ} \mathrm{N}$. Previous BORTAS-B studies have used the NOAA HYbrid Single-Particle Lagrangian Integrated Trajectory (HYSPLIT) model (Draxler and Hess, 1998), driven by meteorological reanalyses data from the National Center for Environmental Prediction (NCEP) Global Data Assimilation Program (GDAS) to interpret ground-based remote-sensing data collected during BORTAS-B (Griffin et al., 2013; Franklin et al., 2014). We find that our Eulerian age of emissions estimates are typically a day older than those determined by the the HYSPLIT model during 19-21 July 2011, when groundbased observations reported elevated concentrations due to biomass burning (Gibson et al., 2013; Griffin et al., 2013; Franklin et al., 2014).

Figure 8 shows that $\bar{A}$ averaged over all BORTAS-B flights is generally consistent with the associated median photochemical age of 6 days, determined using NMVOC ratios (Parrington et al., 2013). The photochemical ages have an interquartile range of 8 to 13 days while $\bar{A}$ has an interquartile range of 5 to 9 days. Splitting the data into individual flights reveals some substantial differences between the photochemical ages and $\bar{A}$. Figure 9 shows that $\bar{A}$ minus photochemical age $(\Delta \tau)$ has distinct frequency distributions within and outwith plumes. Within plumes, the distribution peaks at $\Delta \tau=2-4$ days (median 1.8 days), while outwith plumes there is a relatively flat distribution. We find no significant
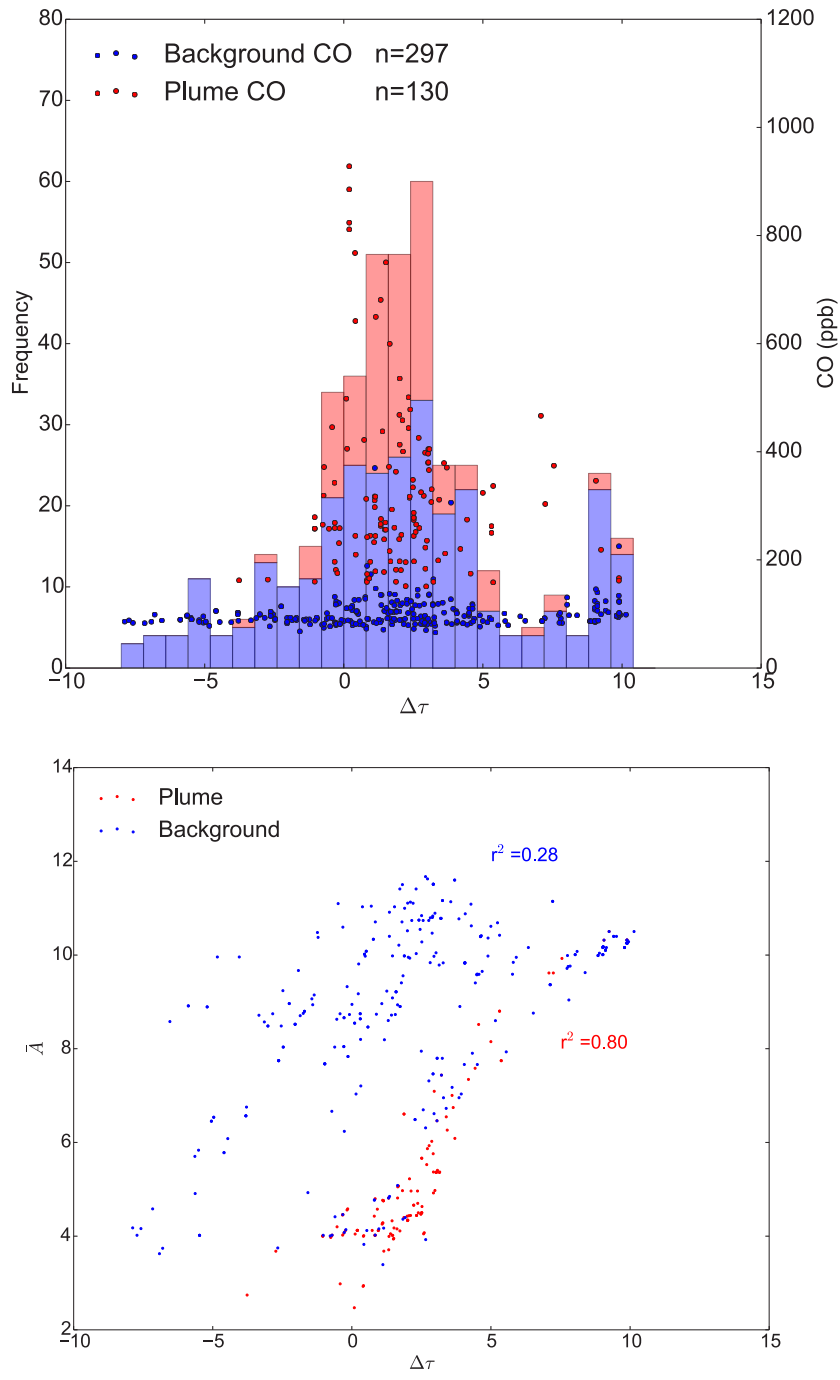

Figure 9. Top panel: frequency of effective age $\bar{A}$ minus photochemical age (days, left axis) and CO concentration (ppb, right axis). The number of measurements $n$ for each classification is shown. Bottom panel: scatter plot of $\Delta \tau$ and $\bar{A}$. Red dots denote $\mathrm{CO}$ concentrations within a plume $\left(\mathrm{CH}_{3} \mathrm{CN}>150 \mathrm{ppt}\right)$; blue dots denote $\mathrm{CO}$ concentrations outwith a plume.

difference to our results if we average the photochemical ages onto the model grid prior to the analysis. Figure 9 shows that high values of $\mathrm{CO}$ relate to $\Delta \tau$ of $2-4$ days, corresponding to a mean (median) fractional difference of $0.44(0.40)$; and a weaker relationship between $\Delta \tau$ outwith plumes, corresponding to a mean (median) fractional difference of 0.11 (0.10). Figure 9 also shows that $\Delta \tau$ increases with $\bar{A}$ within plumes $\left(r^{2}=0.80\right)$ from close to zero at $3-4$ days to $>5$ days for plumes older than 10 days. There is a much weaker relationship between these two age variables outwith plumes $\left(r^{2}=0.28\right)$. 


\section{Concluding remarks}

We used the GEOS-Chem global atmospheric chemistry model to interpret observed variations of $\mathrm{CO}$ taken during the BORTAS-B aircraft campaign over eastern Canada in JulyAugust 2011. We reported a median model minus observed $\mathrm{CO}$ difference of $-0.1 \mathrm{ppb}$, reflecting the long observed tail of elevated $\mathrm{CO}$ concentrations that are not reproduced by the model. The model has a positive bias below observed values of $100 \mathrm{ppb}$ and a negative bias above $300 \mathrm{ppb}$. We found that the larger differences between the model and the observations in the mid troposphere, where we found that pyrogenic $\mathrm{CO}$ peaked. The model has some skill at reproducing the mean observed statistics in the lower troposphere (Spearman's rank correlation $\left.r_{\mathrm{s}}=0.65\right)$, and less in the higher troposphere $\left(r_{\mathrm{s}}=0.19\right)$. The difference in model skill at different altitudes is likely due to (a) misdiagnosing subgrid-scale vertical mixing of pyrogenic material lofted by surface heating due to fires, and (b) errors in biomass burning emission inventories.

Using a linearly decomposed version of the model we found that most of the observed variability in $\mathrm{CO}$ concentration during BORTAS-B was due to Canadian biomass burning, as expected, with a smaller contribution from Siberian biomass burning and NE North American fossil fuel combustion. We used the model to put BORTAS-B into the wider temporal context of 2008-2011. We found that North American biomass burning is broadly constant ( $45 \%$ of total CO) over this period although the spatial distribution of fires varies substantially. The variation of Siberian biomass burning is more extreme, with large contributions to total $\mathrm{CO}$ over North American during some years (2008-2009) and very little activity in other years (2010-2011), reflecting the spatial extent and geographical position of the fires. Based on our analysis of the source contributions to North American $\mathrm{CO}$ during the (limited) four-year period, we conclude that BORTAS-B (2011) was not anomalous.

Previous work has shown that ozone production within biomass burning plumes can be described using photochemical ageing (Parrington et al., 2013). In this paper we describe a new Eulerian method to quantify the effective physical age of emissions $\bar{A}$, taking account of mixing and chemical decay of emitted air masses of varying age. We found that during BORTAS-B, values of $\bar{A}$ for air masses intercepted over Halifax, Nova Scotia are typically 4-11 days old but occasionally as young as two days, corresponding well to analysis of concurrent ground-based observations at the Dalhousie ground station (DGS) in Halifax, NS (Gibson et al., 2013). We found that our Eulerian age of emission estimates are typically a day older than those determined by the the HYSPLIT model during 19-21 July 2011 when ground-based observations reported elevated concentrations due to biomass burning (Gibson et al., 2013; Griffin et al., 2013; Franklin et al., 2014). We attributed this difference in age to our method accounting for older air masses that are not explicitly considered by
HYSPLIT. We compared the values of $\bar{A}$ calculated using our method to the corresponding photochemical ages, using ratios of NMVOCs (Parrington et al., 2013), and found that values of $\bar{A}$ are typically $1-5$ days older. We found that the median difference between the age measures in plumes (defined as $\mathrm{CH}_{3} \mathrm{CN}>150 \mathrm{ppt}$ ) peaks at 3-5 days, compared to a muted distribution for background $\mathrm{CO}$ concentrations, corresponding to a chemical retardation of $50 \%$. We also found that in plumes $\Delta \tau$ increased with physical age $\left(r^{2}=0.80\right)$; this was much less pronounced outwith plumes $\left(r^{2}=0.23\right)$. Based on $\Delta \tau$ within and outwith plumes and on a strong relationship between $\mathrm{CO}$ and, for example, black carbon aerosol during BORTAS-B $\left(r^{2}>0.70\right.$, Taylor et al., 2014), we hypothesize that $\Delta \tau$ variations provide evidence that pyrogenic aerosols slow down the plume photochemistry for many days downwind of the point of burning.

Previous work has shown, using a photochemical model, that the observed ozone tendency of Alaskan forest fire plumes observed over the North Atlantic during 2004 was consistent with a reduced photolysis rate of approximately $20 \%$ that could be due to aerosol loading within/above these plumes (Real et al., 2007). Our analysis of photochemical age versus $\bar{A}$ suggests a larger retardation to the plume photochemistry. One important counter-argument to our analysis of $\Delta \tau$ that could reconcile $\bar{A}$ and photochemical ages is that the photochemical age could have a negative bias. The method, described in detail by Parrington et al. (2013), relies on variation of NMVOC ratios that have different chemical lifetimes against oxidation by $\mathrm{OH}$. As we discuss, the lifetime calculation is anchored by an assumption of a constant $\mathrm{OH}$ concentration. The BORTAS-B data analysis assumed an $\mathrm{OH}$ concentration of $2 \times 10^{6} \mathrm{molec} \mathrm{cm}^{-3}$ that was chosen to be representative of a northern mid-latitude summertime OH concentration (Spivakovsky et al., 2000). Halving (doubling) the assumed $\mathrm{OH}$ concentration would increase (decrease) the photochemical age. For many flights the median value of $\bar{A}$ is substantially higher than the photochemical age. As discussed in Yokelson et al. (2013), there are inherent limitations to using photochemistry as a proxy for the age of emissions. The photochemical age calculation also assumes a constant emission ratio of NMVOCs from the fires, and a constant background concentration. Our method also assumes constant $\mathrm{OH}$ concentrations, but it is much less sensitive to changes in $\mathrm{OH}$ concentration. All values of $\bar{A}$ we report in our domain are well within the e-folding lifetime set by $\mathrm{OH}$, therefore diffusion is the dominant effect on $\bar{A}$ for our timescale. By running our analysis with a doubled and halved lifetime of $\mathrm{CO}$ against $\mathrm{OH}$ oxidation we find that values of $\bar{A}$ differ by less than one day.

Our method of calculating $\bar{A}$ does not consider the size of the fire or the amount of $\mathrm{CO}$ that is emitted. While this will not affect the $\bar{A}$ calculation, it may complicate the interpretation of data. If, for example, old, high-CO air masses mix with young, low-CO air masses our method will assign more weight to the younger air mass and a stronger attri- 
bution to the observed $\mathrm{CO}$ variability. We tried to minimize this issue by using a fixed chemical decay, but some residual of this issue will unavoidably remain. Other measures of age inferred from Lagrangian back-trajectories, say, will suffer from similar problems and in some circumstances will be more problematic if the mixing of different air masses is not considered.

Accounting for biomass burning in regional air quality budgets downwind of fires presents a number of challenges, not least related to the ability of models to predict where plume chemistry will result in net production of $\mathrm{O}_{3}$. It is well established that this production is a function of the pyrogenic emissions (themselves a function of many environmental variables), the associated vertical mixing and transport pathways, and the photochemical environment. Using BORTAS-B, we have only inferred that aerosols have slowed photochemical ageing of plumes; there are insufficient data to characterize directly how the aerosols have affected the photochemical environment within the plume as a function of time. Further studies of similar pyrogenic plumes should include a full suite of aerosol and radiation instruments in addition to gas-phase atmospheric chemistry instruments. This kind of integrative analysis will become progressively more important as we analyse more complex environments such as megacities, where typically a mix of biogenic, anthropogenic, and pyrogenic material is determining ozone photochemistry.

Acknowledgements. This research was supported by the Natural Environment Research Council under grant number NE/F017391/1. D. P. Finch acknowledges NERC studentship NE/K500835/1. P. I. Palmer acknowledges support from his Philip Leverhulme Prize and his Royal Society Wolfson Research Merit Award. D. P. Finch and P. I. Palmer designed the numerical calculations, performed the analysis, and wrote the paper; P. I. Palmer was also the principal BORTAS mission scientist. M. Parrington was a mission scientist on BORTAS, and provided the photochemical ages and comments on the paper.

Edited by: R. MacKenzie

\section{References}

Akagi, S. K., Yokelson, R. J., Wiedinmyer, C., Alvarado, M. J., Reid, J. S., Karl, T., Crounse, J. D., and Wennberg, P. O.: Emission factors for open and domestic biomass burning for use in atmospheric models, Atmos. Chem. Phys., 11, 4039-4072, doi:10.5194/acp-11-4039-2011, 2011.

Atkinson, R. and Arey, J.: Atmospheric degradation of volatile organic compounds., Chem. Rev., 103, 4605-38, doi:10.1021/cr0206420, 2003.

Bey, I., Jacob, D. J., Yantosca, R. M., Logan, J. A., Field, B. D., Fiore, A. M., Li, Q., Liu, H. Y., Mickley, L. J., and Schultz, M. G.: Global modeling of tropospheric chemistry with assim- ilated meteorology: Model description and evaluation, J. Geophys. Res., 106, 23073, doi:10.1029/2001JD000807, 2001.

Bian, H., Colarco, P. R., Chin, M., Chen, G., Rodriguez, J. M., Liang, Q., Blake, D., Chu, D. A., da Silva, A., Darmenov, A. S., Diskin, G., Fuelberg, H. E., Huey, G., Kondo, Y., Nielsen, J. E., Pan, X., and Wisthaler, A.: Source attributions of pollution to the Western Arctic during the NASA ARCTAS field campaign, Atmos. Chem. Phys., 13, 4707-4721, doi:10.5194/acp-13-47072013, 2013.

Draxler, R. R. and Hess, G. D.: An overview of the HYSPLIT 4 modeling system of trajectories, dispersion, and deposition, Aust. Meteor. Mag., 47, 295-308, 1998.

Duncan, B. N., Logan, J. A., Bey, I., Megretskaia, I. A., Yantosca, R. M., Novelli, P. C., Jones, N. B., and Rinsland, C. P.: Global budget of CO, 1988-1997: Source estimates and validation with a global model, J. Geophys. Res., 112, D22301, doi:10.1029/2007JD008459, 2007.

Feng, L., Palmer, P. I., Bösch, H., and Dance, S.: Estimating surface $\mathrm{CO}_{2}$ fluxes from space-borne $\mathrm{CO}_{2}$ dry air mole fraction observations using an ensemble Kalman Filter, Atmos. Chem. Phys., 9, 2619-2633, doi:10.5194/acp-9-2619-2009, 2009.

Fisher, J. A., Jacob, D. J., Purdy, M. T., Kopacz, M., Le Sager, P., Carouge, C., Holmes, C. D., Yantosca, R. M., Batchelor, R. L., Strong, K., Diskin, G. S., Fuelberg, H. E., Holloway, J. S., Hyer, E. J., McMillan, W. W., Warner, J., Streets, D. G., Zhang, Q., Wang, Y., and Wu, S.: Source attribution and interannual variability of Arctic pollution in spring constrained by aircraft (ARCTAS, ARCPAC) and satellite (AIRS) observations of carbon monoxide, Atmos. Chem. Phys., 10, 977-996, doi:10.5194/acp10-977-2010, 2010.

Franklin, J. E., Drummond, J. R., Griffin, D., Pierce, J. R., Waugh, D. L., Palmer, P. I., Parrington, M., Lee, J. D., Lewis, A. C., Rickard, A. R., Taylor, J. W., Allan, J. D., Coe, H., Walker, K. A., Chisholm, L., Duck, T. J., Hopper, J. T., Blanchard, Y., Gibson, M. D., Curry, K. R., Sakamoto, K. M., Lesins, G., Dan, L., Kliever, J., and Saha, A.: A case study of aerosol scavenging in a biomass burning plume over eastern Canada during the 2011 BORTAS field experiment, Atmos. Chem. Phys., 14, 8449-8460, doi:10.5194/acp-14-8449-2014, 2014.

Gerbig, C., Schmitgen, S., Kley, D., Volz-Thoms, A., Dewey, K., Haaks, D., and Volz-Thomas, A.: An improved fast-response vacuum-UV resonance fluorescence CO instrument, J. Geophys. Res., 104, 1699-1704, doi:10.1029/1998JD100031, 1999.

Gibson, M. D., Pierce, J. R., Waugh, D., Kuchta, J. S., Chisholm, L., Duck, T. J., Hopper, J. T., Beauchamp, S., King, G. H., Franklin, J. E., Leaitch, W. R., Wheeler, A. J., Li, Z., Gagnon, G. A., and Palmer, P. I.: Identifying the sources driving observed $\mathrm{PM}_{2.5}$ temporal variability over Halifax, Nova Scotia, during BORTASB, Atmos. Chem. Phys., 13, 7199-7213, doi:10.5194/acp-137199-2013, 2013.

Giglio, L., Randerson, J. T., van der Werf, G. R., Kasibhatla, P. S., Collatz, G. J., Morton, D. C., and DeFries, R. S.: Assessing variability and long-term trends in burned area by merging multiple satellite fire products, Biogeosciences, 7, 1171-1186, doi:10.5194/bg-7-1171-2010, 2010.

Gonzi, S., Feng, L., and Palmer, P. I.: Seasonal cycle of emissions of CO inferred from MOPITT profiles of CO: Sensitivity to pyroconvection and profile retrieval assumptions, Geophys. Res. Lett., 38, L08813, doi:10.1029/2011GL046789, 2011. 
Goode, J. G., Yokelson, R. J., Ward, D. E., Susott, R. A., Babbitt, R. E., Davies, M. A., and Hao, W. M.: Measurements of excess $\mathrm{O}_{3}, \mathrm{CO}_{2}, \mathrm{CO}, \mathrm{CH}_{4}, \mathrm{C}_{2} \mathrm{H}_{4}, \mathrm{C}_{2} \mathrm{H}_{2}, \mathrm{HCN}, \mathrm{NO}, \mathrm{NH}_{3}$, $\mathrm{HCOOH}, \mathrm{CH}_{3} \mathrm{COOH}, \mathrm{HCHO}$, and $\mathrm{CH}_{3} \mathrm{OH}$ in 1997 Alaskan biomass burning plumes by airborne Fourier transform infrared spectroscopy (AFTIR), J. Geophys. Res., 105, 22147, doi:10.1029/2000JD900287, 2000.

Griffin, D., Walker, K. A., Franklin, J. E., Parrington, M., Whaley, C., Hopper, J., Drummond, J. R., Palmer, P. I., Strong, K., Duck, T. J., Abboud, I., Bernath, P. F., Clerbaux, C., Coheur, P.F., Curry, K. R., Dan, L., Hyer, E., Kliever, J., Lesins, G., Maurice, M., Saha, A., Tereszchuk, K., and Weaver, D.: Investigation of $\mathrm{CO}, \mathrm{C}_{2} \mathrm{H}_{6}$ and aerosols in a boreal fire plume over eastern Canada during BORTAS 2011 using ground- and satellite-based observations and model simulations, Atmos. Chem. Phys., 13, 10227-10241, doi:10.5194/acp-13-10227-2013, 2013.

Guenther, A., Karl, T., Harley, P., Wiedinmyer, C., Palmer, P. I., and Geron, C.: Estimates of global terrestrial isoprene emissions using MEGAN (Model of Emissions of Gases and Aerosols from Nature), Atmos. Chem. Phys., 6, 3181-3210, doi:10.5194/acp-63181-2006, 2006.

Jacob, D. J., Crawford, J. H., Maring, H., Clarke, A. D., Dibb, J. E., Emmons, L. K., Ferrare, R. A., Hostetler, C. A., Russell, P. B., Singh, H. B., Thompson, A. M., Shaw, G. E., McCauley, E., Pederson, J. R., and Fisher, J. A.: The Arctic Research of the Composition of the Troposphere from Aircraft and Satellites (ARCTAS) mission: design, execution, and first results, Atmos. Chem. Phys., 10, 5191-5212, doi:10.5194/acp-10-5191-2010, 2010.

Jaffe, D. A. and Wigder, N. L.: Ozone production from wildfires: A critical review, Atmos. Environ., 51, 1-10, doi:10.1016/j.atmosenv.2011.11.063, 2012.

Jones, D. B. A., Bowman, K. W., Palmer, P. I., Worden, J. R., Jacob, D. J., Hoffman, R. N., Bey, I., and Yantosca, R. M.: Potential of observations from the Tropospheric Emission Spectrometer to constrain continental sources of carbon monoxide, J. Geophys. Res. Atmos., 108, 4789, doi:10.1029/2003JD003702, 2003.

Koppmann, R., von Czapiewski, K., and Reid, J. S.: A review of biomass burning emissions, part I: gaseous emissions of carbon monoxide, methane, volatile organic compounds, and nitrogen containing compounds, Atmos. Chem. Phys. Discuss., 5, 1045510516, doi:10.5194/acpd-5-10455-2005, 2005.

Le Breton, M., Bacak, A., Muller, J. B. A., O'Shea, S. J., Xiao, P., Ashfold, M. N. R., Cooke, M. C., Batt, R., Shallcross, D. E., Oram, D. E., Forster, G., Bauguitte, S. J.-B., Palmer, P. I., Parrington, M., Lewis, A. C., Lee, J. D., and Percival, C. J.: Airborne hydrogen cyanide measurements using a chemical ionisation mass spectrometer for the plume identification of biomass burning forest fires, Atmos. Chem. Phys., 13, 92179232, doi:10.5194/acp-13-9217-2013, 2013.

Lewis, A. C., Evans, M. J., Hopkins, J. R., Punjabi, S., Read, K. A., Purvis, R. M., Andrews, S. J., Moller, S. J., Carpenter, L. J., Lee, J. D., Rickard, A. R., Palmer, P. I., and Parrington, M.: The influence of biomass burning on the global distribution of selected non-methane organic compounds, Atmos. Chem. Phys., 13, 851867, doi:10.5194/acp-13-851-2013, 2013.

Liang, Q., Rodriguez, J. M., Douglass, A. R., Crawford, J. H., Olson, J. R., Apel, E., Bian, H., Blake, D. R., Brune, W., Chin, M., Colarco, P. R., da Silva, A., Diskin, G. S., Duncan, B. N., Huey, L. G., Knapp, D. J., Montzka, D. D., Nielsen, J. E., Pawson, S.,
Riemer, D. D., Weinheimer, A. J., and Wisthaler, A.: Reactive nitrogen, ozone and ozone production in the Arctic troposphere and the impact of stratosphere-troposphere exchange, Atmos. Chem. Phys., 11, 13181-13199, doi:10.5194/acp-11-13181-2011, 2011.

Murphy, J. G., Oram, D. E., and Reeves, C. E.: Measurements of volatile organic compounds over West Africa, Atmos. Chem. Phys., 10, 5281-5294, doi:10.5194/acp-10-5281-2010, 2010.

Olivier, J. G. J., Bloos, J. P. J., Berdowski, J. J. M., Visschedijk, A. J. H., and Bouwman, A. F.: A 1990 global emission inventory of anthropogenic sources of carbon monoxide on $1^{\circ} \times{ }^{\circ}$ developed in the framework of EDGAR/GEIA, Chemosph.-Glob. Chang. Sci., 1, 1-17, doi:10.1016/S1465-9972(99)00019-7, 1999.

O'Shea, S. J., Allen, G., Gallagher, M. W., Bauguitte, S. J.-B., Illingworth, S. M., Le Breton, M., Muller, J. B. A., Percival, C. J., Archibald, A. T., Oram, D. E., Parrington, M., Palmer, P. I., and Lewis, A. C.: Airborne observations of trace gases over boreal Canada during BORTAS: campaign climatology, air mass analysis and enhancement ratios, Atmos. Chem. Phys., 13, 1245112467, doi:10.5194/acp-13-12451-2013, 2013.

Palmer, P. I., Jacob, D. J., Jones, D. B. A., Heald, C. L., Yantosca, R. M., and Logan, J. A.: Inverting for emissions of carbon monoxide from Asia using aircraft observations over the western Pacific, J. Geophys. Res., 108, 8828, doi:10.1029/2003JD003397, 2003.

Palmer, P. I., Suntharalingam, P., Jones, D. B. A., Jacob, D. J., Streets, D. G., Fu, Q., Vay, S. A., and Sachse, G. W.: Using $\mathrm{CO}_{2}$ :CO correlations to improve inverse analyses of carbon fluxes, J. Geophys. Res., 111, D12318, doi:10.1029/2005JD006697, 2006.

Palmer, P. I., Parrington, M., Lee, J. D., Lewis, A. C., Rickard, A. R., Bernath, P. F., Duck, T. J., Waugh, D. L., Tarasick, D. W., Andrews, S., Aruffo, E., Bailey, L. J., Barrett, E., Bauguitte, S. J.B., Curry, K. R., Di Carlo, P., Chisholm, L., Dan, L., Forster, G., Franklin, J. E., Gibson, M. D., Griffin, D., Helmig, D., Hopkins, J. R., Hopper, J. T., Jenkin, M. E., Kindred, D., Kliever, J., Le Breton, M., Matthiesen, S., Maurice, M., Moller, S., Moore, D. P., Oram, D. E., O’Shea, S. J., Owen, R. C., Pagniello, C. M. L. S., Pawson, S., Percival, C. J., Pierce, J. R., Punjabi, S., Purvis, R. M., Remedios, J. J., Rotermund, K. M., Sakamoto, K. M., da Silva, A. M., Strawbridge, K. B., Strong, K., Taylor, J., Trigwell, R., Tereszchuk, K. A., Walker, K. A., Weaver, D., Whaley, C., and Young, J. C.: Quantifying the impact of BOReal forest fires on Tropospheric oxidants over the Atlantic using Aircraft and Satellites (BORTAS) experiment: design, execution and science overview, Atmos. Chem. Phys., 13, 6239-6261, doi:10.5194/acp-13-6239-2013, 2013.

Parrington, M., Palmer, P. I., Henze, D. K., Tarasick, D. W., Hyer, E. J., Owen, R. C., Helmig, D., Clerbaux, C., Bowman, K. W., Deeter, M. N., Barratt, E. M., Coheur, P.-F., Hurtmans, D., Jiang, Z., George, M., and Worden, J. R.: The influence of boreal biomass burning emissions on the distribution of tropospheric ozone over North America and the North Atlantic during 2010, Atmos. Chem. Phys., 12, 2077-2098, doi:10.5194/acp-12-20772012, 2012.

Parrington, M., Palmer, P. I., Lewis, A. C., Lee, J. D., Rickard, A. R., Di Carlo, P., Taylor, J. W., Hopkins, J. R., Punjabi, S., Oram, D. E., Forster, G., Aruffo, E., Moller, S. J., Bauguitte, S. J.-B., Allan, J. D., Coe, H., and Leigh, R. J.: Ozone photochemistry in 
boreal biomass burning plumes, Atmos. Chem. Phys., 13, 73217341, doi:10.5194/acp-13-7321-2013, 2013.

Parrish, D. D., Stohl, A., Forster, C., Atlas, E. L., Blake, D. R., Goldan, P. D., Kuster, W. C., and de Gouw, J. a.: Effects of mixing on evolution of hydrocarbon ratios in the troposphere, J. Geophys. Res., 112, D10S34, doi:10.1029/2006JD007583, 2007.

Real, E., Law, K. S., Weinzierl, B., Fiebig, M., Petzold, A., Wild, O., Methven, J., Arnold, S., Stohl, A., Huntrieser, H., Roiger, A., Schlager, H., Stewart, D., Avery, M., Sachse, G., Browell, E., Ferrare, R., and Blake, D.: Processes influencing ozone levels in Alaskan forest fire plumes during long-range transport over the North Atlantic, J. Geophys. Res., 112, D10S41, doi:10.1029/2006JD007576, 2007.

Reid, J. S., Hyer, E. J., Prins, E. M., Westphal, D. L., Zhang, J., Wang, J., Christopher, S. A., Curtis, C. A., Schmidt, C. C., Eleuterio, D. P., Richardson, K. A., and Hoffman, J. P.: Global Monitoring and Forecasting of Biomass-Burning Smoke: Description of and Lessons From the Fire Locating and Modeling of Burning Emissions (FLAMBE) Program, IEEE J. Sel. Top. Appl. Earth Obs. Remote Sens., 2, 144-162, doi:10.1109/JSTARS.2009.2027443, 2009.
Spivakovsky, C. M., Logan, J. A., Montzka, S. A., Balkanski, Y. J., Foreman-Fowler, M., Jones, D. B. A., Horowitz, L. W., Fusco, A. C., Brenninkmeijer, C. A. M., Prather, M. J., Wofsy, S. C., and McElroy, M. B.: Three-dimensional climatological distribution of tropospheric $\mathrm{OH}$ : Update and evaluation, J. Geophys. Res.Atmos., 105, 8931-8980, doi:10.1029/1999JD901006, 2000.

Taylor, J. W., Allan, J. D., Allen, G., Coe, H., Williams, P. I., Flynn, M. J., Le Breton, M., Muller, J. B. A., Percival, C. J., Oram, D., Forster, G., Lee, J. D., Rickard, A. R., and Palmer, P. I.: Size-dependent wet removal of black carbon in Canadian biomass burning plumes, Atmos. Chem. Phys. Discuss., 14, 19469-19513, doi:10.5194/acpd-14-19469-2014, 2014.

Tereszchuk, K. A., Moore, D. P., Harrison, J. J., Boone, C. D., Park, M., Remedios, J. J., Randel, W. J., and Bernath, P. F.: Observations of peroxyacetyl nitrate (PAN) in the upper troposphere by the Atmospheric Chemistry Experiment-Fourier Transform Spectrometer (ACE-FTS), Atmos. Chem. Phys., 13, 5601-5613, doi:10.5194/acp-13-5601-2013, 2013.

Yokelson, R. J., Andreae, M. O., and Akagi, S. K.: Pitfalls with the use of enhancement ratios or normalized excess mixing ratios measured in plumes to characterize pollution sources and aging, Atmos. Meas. Tech., 6, 2155-2158, doi:10.5194/amt-62155-2013, 2013. 